\title{
Synthesis and Turnover of Mitochondrial Ribonucleic Acid in HeLa Cells: the Mature Ribosomal and Messenger Ribonucleic Acid Species Are Metabolically Unstable
}

\author{
ROBERT GELFAND $\dagger$ AND GIUSEPPE ATTARDI* \\ Division of Biology, California Institute of Technology, Pasadena, California 91125
}

Received 26 January 1981/Accepted 31 March 1981

\begin{abstract}
The synthesis rates and half-lives of the individual mitochondrial ribosomal ribonucleic acid (RNA) and polyadenylic acid-containing RNA species in HeLa cells have been determined by analyzing their kinetics of labeling with $\left[5-{ }^{3} \mathrm{H}\right]-$ uridine and the changes in specific activity of the mitochondrial nucleotide precursor pools. In one experiment, a novel method for determining the nucleotide precursor pool specific activities, using nascent RNA chains, has been utilized. All mitochondrial RNA species analyzed were found to be metabolically unstable, with half-lives of 2.5 to $3.5 \mathrm{~h}$ for the two ribosomal RNA components and between 25 and $90 \mathrm{~min}$ for the various putative messenger RNAs. A cordycepin "chase" experiment yielded half-life values for the messenger RNA species which were, in general, larger by a factor of 1.5 to 2.5 than those estimated in the labeling kinetics experiments. On the basis of previous observations, a model is proposed whereby the rate of mitochondrial RNA decay is under feedback control by some mechanism linked to RNA synthesis or processing. A short half-life was determined for five large polyadenylated RNAs, which are probably precursors of mature species. A rate of synthesis of one to two molecules per minute per cell was estimated for the various $\mathrm{H}$-strand-coded messenger RNA species, and a rate of synthesis 50 to 100 times higher was estimated for the ribosomal RNA species. These data indicate that the major portion of the $\mathrm{H}$-strand in each mitochondrial deoxyribonucleic acid molecule is transcribed very infrequently, possibly as rarely as once or twice per cell generation. Furthermore, these results are consistent with a previously proposed model of $\mathrm{H}$-strand transcription in the form of a single polycistronic molecule.
\end{abstract}

In the past few years, a deep insight into the gene organization of human mitochondrial deoxyribonucleic acid (mtDNA) has been provided by a detailed analysis of HeLa cell mtDNA transcription $(5,6,36,37)$ and sequencing studies on human mtDNA (B. G. Barrell, S. Anderson, A. T. Bankier et al., in H. Weiss and W. Sebald, ed., 31st Mosbach Colloquium on Biological Chemistry of Organelle Formation, in press) and mitochondrial ribonucleic acids (RNAs) (18, $29 a, 38,38 a)$. It is now well established that this DNA codes for 2 ribosomal RNA (rRNA) species (1), at least 22 transfer RNA (tRNA) species $(6,10,29)$, which appear to form a complete set for mitochondrial protein synthesis, and a large number of polyadenylic acid [poly(A)]-containing RNAs (5). Among the latter, several putative messenger RNAs (mRNA's) have been identified (RNAs 5, 7, 9, and 11 to 17) on the basis of their relative abundance and association with

\footnotetext{
† Present address: Department of Biology, Purdue University, West Lafayette, IN 47907.
}

polysomes (5), their structural properties (29a; G. Attardi, P. Cantatore, E. Ching, S. Crews, R. Gelfand, C. Merkel, J. Montoya, and D. Ojala, in Second International Congress on Cell Biology, West Berlin, in press), and their correspondence with significant reading frames in mtDNA (B. G. Barrell et al., in press). Furthermore, for five of these mRNA's, the identities of the polypeptides encoded in their sequences have been determined by correlating the RNA and corresponding DNA sequences with protein sequence data $(11,16)$ and with known yeast gene sequences $(33,44)$.

It is known that both strands of HeLa cell mtDNA are transcribed over their entire length $(2,3,30)$; furthermore, recent experiments have shown that the light (L) strand is transcribed at a rate which is two or three times higher than the heavy $(\mathrm{H})$ strand (13), in contrast to the fact that the H-strand contains most of the genes identified in mtDNA; however, the majority of the L-strand transcripts have a half-life much 
shorter than those of the $\mathrm{H}$-strand transcripts and do not accumulate in mitochondria to any significant extent (3). There is evidence indicating that both strands are transcribed in the form of a single or a few large molecules $(3,5,37)$. Recently, a model of transcription of the $\mathrm{H}$ strand has been proposed whereby a single polycistronic transcript is processed by precise endonucleolytic cleavages to yield the mature tRNA, rRNA, and mRNA species (9, 38a).

The two rRNA species have been found to be unstable after a block of RNA synthesis by ethidium bromide or cordycepin $(45,46)$. By contrast, under other experimental conditions entailing severe inhibition of RNA synthesis, the rate of mitochondrial protein synthesis has been shown to be unaffected for a prolonged time, pointing to the stability of the RNAs involved $(22,28)$. In this work, advantage has been taken of the availability of a procedure for isolating the mtDNA-coded RNA species in pure form (18; R. A. Gelfand, Ph.D. thesis, California Institute of Technology, Pasadena, 1980) to analyze the metabolic behavior of these species under physiological or near-physiological conditions. The synthesis rates and metabolic halflives of the individual RNAs were determined by using an approach derived from Galau et al. (23), involving the measurement of the kinetics of labeling of each RNA and of the changes with time of the precursor pool specific activity. The metabolic stability of the RNAs after cordycepin block was also determined. The striking result of this analysis is that both the mature rRNA and mRNA species are metabolically unstable, with half-lives of 2.5 to $3.5 \mathrm{~h}$ for the two rRNA components and ranging between 25 and $90 \mathrm{~min}$ for the different putative mRNA's.

\section{MATERIALS AND METHODS}

Cell growth and labeling conditions. HeLa cells were grown in suspension. In the experiments in which the cells were maintained in exponential growth throughout the labeling period, cell cultures at $10^{5}$ cells per $\mathrm{ml}$ were exposed, unless otherwise specified, to ${ }^{32} \mathrm{P}$ ]orthophosphate $(5 \mu \mathrm{Ci} / \mathrm{ml})$ for $24 \mathrm{~h}$ and to [5${ }^{3} \mathrm{H}$ ] uridine $(2.5 \mu \mathrm{Ci} / \mathrm{ml})$ for different lengths of time in modified Eagle medium containing $5 \times 10^{-4} \mathrm{M}$ phosphate, supplemented with $5 \%$ dialyzed calf serum. In the experiments in which the labeling was carried out at a high density, cell suspensions concentrated to 1.0 $\times 10^{6}$ to $1.5 \times 10^{6}$ cells per ml from exponentially growing cultures were exposed to $\left[{ }^{32} \mathrm{P}\right]$ orthophosphate $(20 \mu \mathrm{Ci} / \mathrm{ml})$ for 3 or $3.5 \mathrm{~h}$ and to $\left[5-{ }^{3} \mathrm{H}\right]$ uridine $(20 \mu \mathrm{Ci} /$ $\mathrm{ml}$ ) for different lengths of time in medium containing $4 \times 10^{-5} \mathrm{M}$ phosphate. Pulse-labeling with $\left[5{ }^{3} \mathrm{H}\right]$ uridine after cordycepin treatment was carried out by exposing cell suspensions at $1.5 \times 10^{6}$ cells per ml to the precursor $(33 \mu \mathrm{Ci} / \mathrm{ml})$ for 10 min after different periods $(0,2.5,5$, and $15 \mathrm{~min})$ of treatment with the drug $(50 \mu \mathrm{g} / \mathrm{ml})$. In the cordycepin chase experiment, labeling of the cells was performed by exposing cell suspensions at $10^{6}$ cells per $\mathrm{ml}$ to $\left.{ }^{32} \mathrm{P}\right]$ orthophosphate $(30 \mu \mathrm{Ci} / \mathrm{ml})$ for $2.5 \mathrm{~h}$ in the presence of $4 \times 10^{-5} \mathrm{M}$ phosphate before addition of cordycepin $(50 \mu \mathrm{g} / \mathrm{ml})$.

Subcellular fractionation. A crude mitochondrial fraction was prepared from samples of $1.3 \times 10^{8}$ to 2.0 $\times 10^{8}$ cells, as described previously (5). The mitochondrial fraction was treated with nuclease(s) to destroy contaminating nuclear and cytoplasmic nucleic acids by either of two methods. In some experiments, the fraction was incubated with ribonuclease $\mathrm{A}(5 \mu \mathrm{g} / \mathrm{ml})$ plus deoxyribonuclease I $(50 \mu \mathrm{g} / \mathrm{ml}$; Worthington Diagnostics) for $15 \mathrm{~min}$ at $0^{\circ} \mathrm{C}$ in 2 to $3 \mathrm{ml}$ of $0.01 \mathrm{M}$ tris(hydroxymethyl)aminomethane (Tris) (pH 6.7) $\left(25^{\circ} \mathrm{C}\right)-5 \times 10^{-4} \mathrm{M} \mathrm{MgCl}_{2}$, then washed three times by pelleting $(9 \mathrm{krpm}, 10 \mathrm{~min}$, in a Sorvall SS-34 rotor) and resuspension in $0.25 \mathrm{M}$ sucrose- 0.01 Tris $(\mathrm{pH} \mathrm{6.7)-}$ $0.45 \mathrm{M} \mathrm{NaCl}$, and finally lysed. In other experiments, the mitochondrial fraction was treated with $15 \mathrm{U}$ of micrococcal nuclease (Worthington) per $\mathrm{ml}$ for $15 \mathrm{~min}$ at room temperature in 2 to $3 \mathrm{ml}$ of $0.25 \mathrm{M}$ sucrose$0.01 \mathrm{M}$ Tris ( $\mathrm{pH} 8.0)-10^{-3} \mathrm{M} \mathrm{CaCl}_{2}$; the mitochondrial suspension was then cooled to $0^{\circ} \mathrm{C}$, and ethylene glycol-bis ( $\beta$-aminoethyl ether)- $N, N$-tetraacetic acid was added to $2 \times 10^{-3} \mathrm{M}$ to inhibit the nuclease activity. After $5 \mathrm{~min}$, a large excess of cold buffer $(0.25 \mathrm{M}$ sucrose, 0.01 Tris [pH 7.4], $0.01 \mathrm{M}$ ethylenediaminetetraacetic acid) was added, and the mitochondria were pelleted (9 $\mathrm{krpm}, 10 \mathrm{~min}$, Sorvall SS-34 rotor). In some experiments, mitochondrial polysomes were isolated by lysing the mitochondrial fraction with Triton $\mathrm{X}-100$, spinning down the insoluble structures, and running the cleared lysate on a sucrose gradient, as previously reported (34).

Extraction and analysis of the RNA. Total mitochondrial RNA was isolated from the nucleasetreated mitochondria by lysis of the organelles in 2 to $3 \mathrm{ml}$ of sodium dodecyl sulfate buffer $(0.01 \mathrm{M}$ Tris [ $\mathrm{pH}$ 7.4], $0.001 \mathrm{M}$ ethylenediaminetetraacetic acid, $0.1 \mathrm{M}$ $\mathrm{NaCl}, 1 \%$ sodium dodecyl sulfate), followed by pronase treatment $(100 \mu \mathrm{g} / \mathrm{ml}, 1 \mathrm{~h}$ at room temperature) and phenol-chloroform-isoamyl alcohol extraction, as previously described (5). In some experiments, RNA was extracted from mitochondrial polysomes separated on sucrose gradients. Fractionation of the RNA by chromatography on oligodeoxythymidylic acid [oligo(dT) ]cellulose (T3 form; Collaborative Research) columns was performed as detailed earlier (5). Electrophoretic fractionation of the RNA samples through $1.4 \%$ agarose- $5 \mathrm{mM} \mathrm{CH} \mathrm{CH}_{3} \mathrm{HgOH}$ slab gels was carried out as described earlier (5), except that the electrophoresis buffer contained $10^{-4} \mathrm{M}$ instead of $10^{-3} \mathrm{M}$ ethylenediaminetetraacetic acid. After the gels were dried and subjected to autoradiography, areas of interest were located on the autoradiograms. The corresponding portions of the dried gel were then cut out and heated to $90^{\circ} \mathrm{C}$ for $20 \mathrm{~min}$ in $1 \mathrm{ml}$ of low-salt buffer $(0.01 \mathrm{M}$ Tris [pH 7.4], $0.001 \mathrm{M}$ ethylenediaminetetraacetic acid); more than $95 \%$ of the radioactivity in the dried gel was eluted by this technique. In some experiments, portions of individual tracks from dried slab gels were sliced sequentially into $1-\mathrm{mm}$ sections on a Mickel gel slicer, and the radioactivity in the individual sections was eluted as described above. 
Isolation of RNA from transcription complexes. Transcription complexes of mtDNA were isolated, as previously described $(4,13)$, by sucrose gradient centrifugation of sodium dodecyl sulfate lysates of isopycnically purified mitochondria from samples of $\sim 2.0 \times 10^{8}$ cells labeled, at high density, with $\left[{ }^{32} \mathrm{P}\right]-$ orthophosphate for $3 \mathrm{~h}$ and with $\left[5-{ }^{3} \mathrm{H}\right]$ uridine for various lengths of time, as detailed above. The nucleic acids of the transcription complexes were isolated by pronase treatment and several phenol-chloroform extractions; after ethanol precipitation and centrifugation, each sample (in $1 \mathrm{ml}$ of $0.05 \mathrm{M}$ Tris [pH 6.7], $0.025 \mathrm{M} \mathrm{KCl}, 0.0025 \mathrm{M} \mathrm{MgCl}_{2}$ ) was digested with electrophoretically purified deoxyribonuclease I (Boehringer Mannheim Corp.) at $100 \mu \mathrm{g} / \mathrm{ml}$ for $1 \mathrm{~h}$ at room temperature and deproteinized by pronase-sodium dodecyl sulfate treatment and phenol-chloroform extraction.

RNA-DNA hybridization. The isolation of HeLa cell mtDNA and the separation of $\mathrm{H}$ - and L-strands were carried out as reported earlier (2). Hybridization of RNA from transcription complexes with mtDNA Lstrands under conditions of DNA excess $(0.5 \mu \mathrm{g}$ per incubation mixture containing RNA from about $10^{8}$ cells) was performed as previously described (5). The nonhybridized RNA was digested with ribonuclease, and the 5\% trichloroacetic acid-precipitable material in each sample was subjected to alkali hydrolysis (0.5 $\mathrm{N} \mathrm{NaOH}, 18 \mathrm{~h}, 37^{\circ} \mathrm{C}$ ); after trichloroacetic acid precipitation in the presence of $50 \mu \mathrm{g}$ of bovine serum albumin, centrifugation, and neutralization of the supernatant, the alkali-hydrolyzable radioactivity was determined.

Purification of NTPs. Isolation of an acid-soluble fraction containing the nucleoside triphosphates (NTPs) was carried out with the charcoal binding and elution method described by Humphreys (26). Separation of the nucleoside triphosphates by chromatography on polyethyleneimine-cellulose thin-layer chromatographic plates was performed by the method of Neuhard et al. (32), procedure 1, and in some cases, by the method of Cashel et al. (15). The radioactivity associated with each NTP spot (recognizable from the ultraviolet absorption of the marker) was analyzed by eluting (32) material from the center of the spot and from a ring surrounding the center: the specific activities of the two samples were essentially identical, arguing against the presence of closely migrating contaminants.

\section{RESULTS}

Isolation and fractionation of mitochondrial RNA species. A prerequisite for meaningful metabolic studies on HeLa cell mitochondrial RNA was a procedure for isolation in pure form of the mitochondrial RNA species. This would eliminate the need of using inhibitors of nuclear RNA synthesis to suppress the labeling of contaminating extramitochondrial RNA. In the early part of this work, a purification of mitochondrial RNA was achieved by treating the mitochondrial fraction with ribonuclease and deoxyribonuclease to destroy the extrami- tochondrial nucleic acids and then washing the mitochondria extensively before sodium dodecyl sulfate lysis and RNA extraction. This method gave reasonably pure RNA but in variable yields, possibly due to ribonuclease digestion of the RNA in damaged organelles. A substantial improvement in the consistency of RNA yield was obtained by substituting micrococcal nuclease for the ribonuclease plus deoxyribonuclease in the digestion of extramitochondrial nucleic acids (18; Gelfand, Ph.D. thesis). The advantage of using this enzyme is that it can be easily inhibited by chelating agents, eliminating the need for extensive washing of the mitochondria. Such a procedure has been used in most of the experiments described here. Figure $1 \mathrm{~B}$ shows the electrophoretic pattern, after $\mathrm{CH}_{3} \mathrm{HgOH}$ agarose slab gel electrophoresis, of total poly(A)containing RNA extracted from micrococcal nuclease-treated mitochondria of HeLa cells labeled with $\left[{ }^{32} \mathrm{P}\right]$ orthophosphate in the absence of inhibitors of nuclear RNA synthesis. This pattern is identical in every detail to that of the poly(A)-containing RNA extracted from the crude mitochondrial fraction (untreated) of cells labeled with $\left[{ }^{32} \mathrm{P}\right]$ orthophosphate in the presence of camptothecin to block all high-molecular-weight nuclear RNA synthesis (5; Fig. 1A). All RNA species recognizable in the patterns of Fig. 1 have been shown to be coded for by mtDNA, and their complementary sequences have been precisely localized on the mitochondrial genome by mapping and sequencing approaches $(29 a, 38,38 a)$ (Fig. 1C). The above observations indicate that there is no detectable nuclear DNA-coded RNA component in human mitochondria.

Measurement of labeling of individual RNA species. The first approach used to determine the half-lives of mitochondrial RNAs was to measure the kinetics of labeling of the individual rRNA and poly(A)-containing RNA components during exposure of HeLa cells to [5${ }^{3} \mathrm{H}$ ] uridine. To detect the individual components by autoradiography and to provide an internal standard to normalize the ${ }^{3} \mathrm{H}$ data for differences in recovery of the individual RNA species from time point to time point, the cells were labeled with $\left[{ }^{32} \mathrm{P}\right]$ orthophosphate before and during the exposure to $\left[{ }^{3} \mathrm{H}\right]$ uridine. Two sets of conditions for labeling were used. According to one set of conditions, a cell suspension at relatively low density $\left(10^{5}\right.$ cells per $\left.\mathrm{ml}\right)$. was exposed to $\left[{ }^{32} \mathrm{P}\right]$ orthophosphate in medium containing a relatively high phosphate concentration $\left(5 \times 10^{-4}\right.$ $M)$; at various times before harvesting (carried out after $24 \mathrm{~h}$ of ${ }^{32} \mathrm{P}$ labeling), samples were exposed to $\left[5-{ }^{3} \mathrm{H}\right]$ uridine. A control experiment showed that, under conditions of ${ }^{32} \mathrm{P}$ labeling 

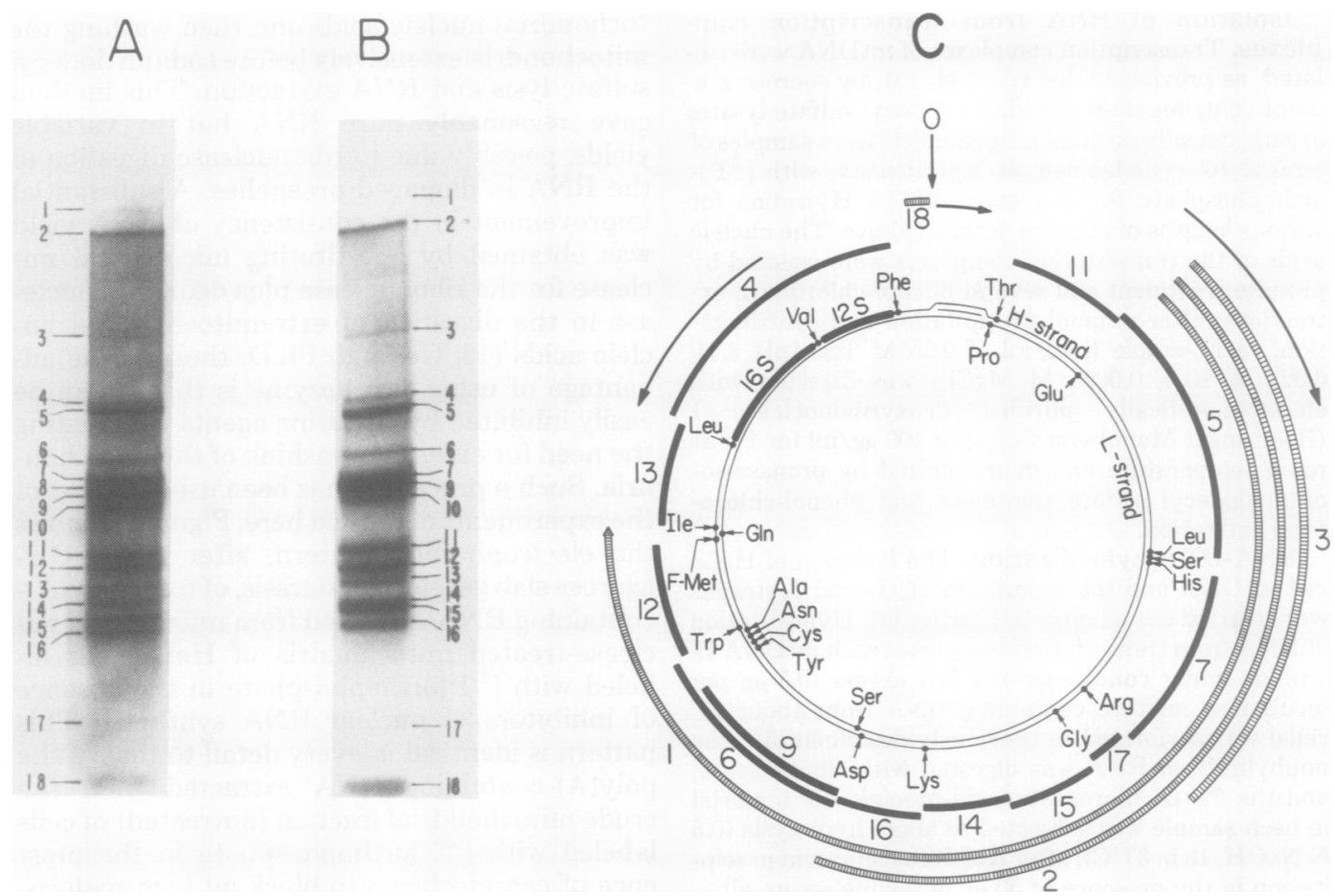

Fig. 1. Autoradiograms, after electrophoresis through agarose- $\mathrm{CH}_{3} \mathrm{HgOH}$ slab gels, of the poly(A)-containing mitochondrial RNA from HeLa cells. (A) RNA extracted from the mitochondrial fraction (untreated) of cells labeled with ${ }^{32}$ PJorthophosphate in the presence of $20 \mu \mathrm{g}$ of camptothecin per ml; (B) RNA extracted from the micrococcal nuclease-treated mitochondrial fraction of cells labeled with [ $\left.{ }^{32} P\right]$ orthophosphate in the absence of inhibitors of nuclear RNA synthesis. (C) Genetic and transcription maps of the HeLa cell mitochondrial genome. The two inner circles show the positions of the two rRNA genes (36), and those of the tRNA genes, as derived from the mtDNA sequence (18; Barrell et al., in press). Mapping positions of the polyadenylated $H$-strand transcripts are indicated by the black bars; those of the L-strand transcripts are indicated by the hatched bars. Left and right arrows indicate the direction of $H$-and $L$-strand transcription, respectively (modified from reference 37 ).

similar to those described above, the cells grow exponentially for at least $48 \mathrm{~h}$, i.e., more than two generations. Under the second set of conditions of labeling, a cell suspension concentrated to a high density $\left(1.0 \times 10^{6}\right.$ to $1.5 \times 10^{6}$ cells per $\mathrm{ml}$ ) from an exponentially growing culture was exposed to a high $\left[{ }^{32} \mathrm{P}\right]$ orthophosphate level in medium containing a low phosphate concentration $\left(4 \times 10^{-5} \mathrm{M}\right)$; at various times before harvesting (after 3 or $3.5 \mathrm{~h}$ of ${ }^{32} \mathrm{P}$ labeling), samples were exposed to $\left[{ }^{3} \mathrm{H}\right]$ uridine. Although under the latter set of conditions only limited growth occurred, this method had the advantage of labeling the mitochondrial RNA precursor pools with ${ }^{32} \mathrm{P}$ to a sufficiently high degree to allow the direct determination of their specific activity (see below).

After labeling, the RNA was extracted from the whole nuclease-treated mitochondria, or from polysomal structures derived from them, and separated into an oligo(dT)-bound and an
oligo(dT)-unbound fraction. Both fractions were then run through $\mathrm{CH}_{3} \mathrm{HgOH}$-agarose slab gels. The individual RNA species identified in the autoradiogram were cut out of the dried gel and analyzed for both ${ }^{3} \mathrm{H}$ and ${ }^{32} \mathrm{P}$ radioactivity, as detailed in Materials and Methods. In two experiments, the dried gels were serially sliced into 1-mm sections to analyze in detail the ${ }^{3} \mathrm{H}$ and ${ }^{32} \mathrm{P}$ profiles. One such experiment is illustrated in Fig. 2. It appears that, even after the shortest $\left[{ }^{3} \mathrm{H}\right]$ uridine pulse $(30 \mathrm{~min})$, the ${ }^{3} \mathrm{H}$ profile follows the ${ }^{32} \mathrm{P}$ profile closely, and no evidence of ${ }^{3} \mathrm{H}$ labeled peaks not corresponding to ${ }^{32} \mathrm{P}$-labeled peaks is observed (Fig. 2A). Figure 2B shows the patterns thus obtained for two of the poly(A)containing RNA components (RNAs 11 and 12) after different lengths of $\left[{ }^{3} \mathrm{H}\right]$ uridine labeling. In the experiments in which the gel tracks were serially sliced, the ${ }^{3} \mathrm{H} /{ }^{32} \mathrm{P}$ ratios of the peak fractions in each pattern were used for the purpose of calculating the half-lives of the corre- 

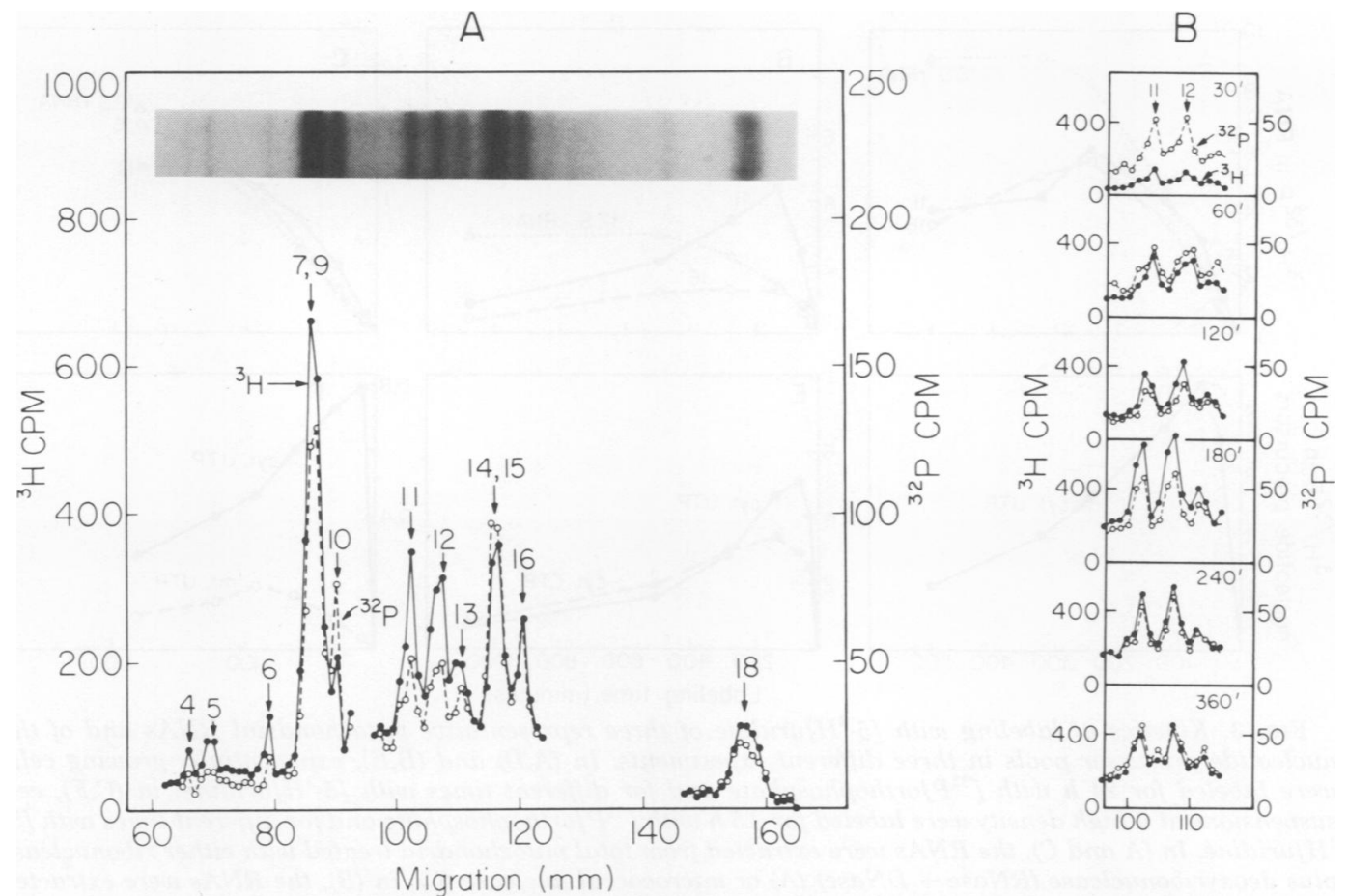

FIG. 2. Analysis by serial gel slicing of the labeling of poly(A)-containing mitochondrial RNA species separated on an agarose- $\mathrm{CH}_{3} \mathrm{HgOH}$ slab gel. (A) A track containing the $\mathrm{RNA}$ from polysomes of exponentially growing cells labeled for $24 \mathrm{~h}$ with $\left[{ }^{32} \mathrm{P}\right]$ orthophosphate and for $1 \mathrm{~h}$ with $\left[5 \cdot{ }^{3} \mathrm{H}\right]$ uridine was sliced through most of its length, and the RNA in each slice was eluted and counted. For the purpose of identification, the positions of the peaks in this plot have been aligned with the positions of the corresponding RNA species in the autoradiogram. (B) Labeling patterns obtained for poly(A)-containing RNAs 11 and 12 derived from cell cultures exposed for different lengths of time to $\left[5 \cdot{ }^{3} \mathrm{H}\right]$ uridine.

sponding RNA species.

Measurement of the specific activity of the RNA precursor pools. To interpret the labeling kinetics of the various RNA species in terms of rates of synthesis and decay, the specific activities of the mitochondrial RNA precursor pools were determined, as ${ }^{3} \mathrm{H} /{ }^{32} \mathrm{P}$ ratios, as detailed in Materials and Methods. In an experiment carried out under conditions of exponential growth, the labeling of the mitochondrial uridine triphosphate (UTP) pool was found to be saturated at around $50 \mathrm{~min}$ and to decline over the next $50 \mathrm{~min}$, whereas the labeling of mitochondrial cytidine triphosphate (CTP) was delayed, reaching its maximum at sometime near 100 min. In the same experiment, the kinetics of labeling of the cytoplasmic UTP and CTP pools was similar to that of the mitochondrial pools, except that the cytoplasmic CTP reached saturation of labeling earlier than the mitochondrial CTP pool. In this experiment, the ${ }^{32} \mathrm{P}$ labeling of the mitochondrial UTP and CTP pools was quite low, due to the high phosphate concentration in the medium. Therefore, in later experi- ments involving exponentially growing cultures, advantage was taken of the general similarity in kinetics of labeling of the cytoplasmic and mitochondrial pools by utilizing the cytoplasmic pool values to calculate the rates of synthesis and decay of the various RNA species. In the experiments involving labeling of the cells in low-phosphate medium at high cell concentration, the mitochondrial pool specific activities were directly determined and used in the analysis of the data.

Kinetics of labeling of mitochondrial RNA species. Figure 3 shows the kinetics of labeling, during continuous cell exposure to [5${ }^{3} \mathrm{H}$ ] uridine, of $12 \mathrm{~S}$ rRNA and two representative poly(A)-containing RNAs (RNAs 11 and 16), and of the precursor nucleotide pools, in three different experiments utilizing either exponentially growing cells (Fig. 3A,D and B,E) or highcell-density suspensions (Fig. 3C,F). The RNA species analyzed here were isolated either from the total mitochondrial fraction (Fig. 3A and C) or from partially purified polysomal structures (Fig. 3B). The labeling profiles of the three 

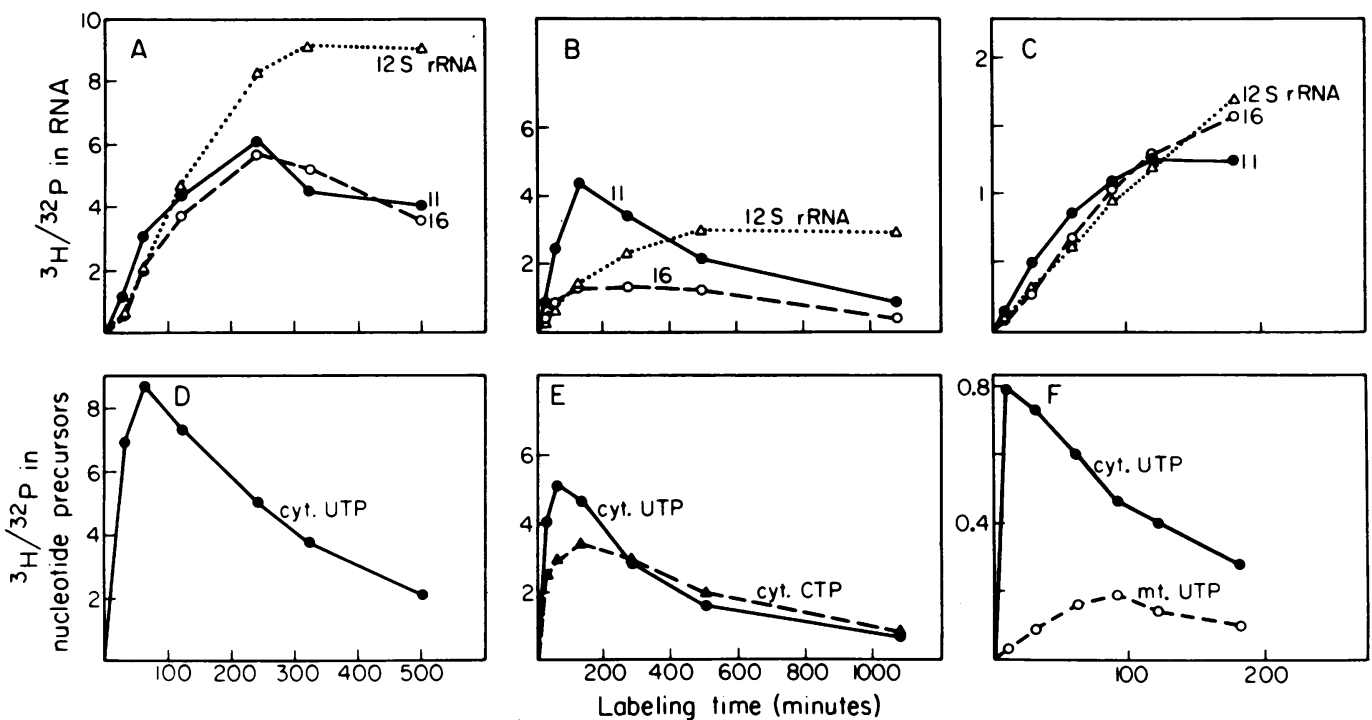

Fig. 3. Kinetics of labeling with $\left[5 \cdot{ }^{3} \mathrm{H}\right]$ uridine of three representative mitochondrial RNAs and of the nucleotide precursor pools in three different experiments. In $(A, D)$ and $(B, E)$, exponentially growing cells were labeled for 24 h with $\left[{ }^{32} P\right]$ orthophosphate and for different times with $\left[5{ }^{3} \mathrm{H}\right]$ uridine; in $(C, F)$, cell suspensions at a high density were labeled for $3.5 \mathrm{~h}$ with $\left.{ }^{32} \mathrm{P}\right]$ orthophosphate and for different times with [5. ${ }^{3} \mathrm{H}$ ] uridine. In (A and C), the RNAs were extracted from total mitochondria treated with either ribonuclease plus deoxyribonuclease (RNase + DNase) (A) or micrococcal nuclease (C); in (B), the RNAs were extracted from partially purified polysomes isolated from RNase + DNase-treated mitochondria.

species shown in Fig. 3 are fairly similar in the three experiments. In particular, the labeling of 12S rRNA appears to reach saturation at between 300 and $500 \mathrm{~min}$ and remains nearly constant over the next several hours. By contrast, the labeling of RNAs 11 and 16 reaches a maximum at between 100 and $200 \mathrm{~min}$ and then slowly declines; in these experiments, and in another experiment (not shown) carried out under the same conditions as the experiment illustrated in Fig. 3C, RNA 11 consistently appears to be more rapidly labeled than RNA 16 and to lose radioactivity faster after reaching saturation. The labeling profiles indicate that the $12 \mathrm{~S}$ rRNA has a longer half-life than RNAs 11 and 16 , and RNA 11 is somewhat less stable than RNA 16. The labeling profiles obtained for the other poly(A)-containing RNAs were very similar to the profile of either RNA 11 or RNA 16 or were intermediate between them.

Determination of the half-life of mitochondrial RNA species. The RNA and precursor pool labeling data discussed above were used to calculate the half-lives and synthesis rate constants of the mitochondrial RNA species by utilizing the following equation (23):

$$
\mathrm{d} R(t) / \mathrm{d} t=k_{s} S(t)-k_{d} R(t)
$$

where $R(t)$ is the amount of radioactivity in a given RNA species at time $t, S(t)$ is the specific activity of the precursor pool at time $t, k_{s}$ is the rate constant of synthesis, and $k_{d}$ is the rate constant of decay. It should be noted that, in the present application, $k_{s}$ represents the rate of appearance in mitochondria of the individual RNA species and not the rate of transcription of their coding sequences. This equation assumes that the rate of synthesis per cell of the particular RNA species is constant and that this RNA decays with first-order (stochastic) kinetics. The latter assumption has been shown to be true for a variety of mRNA's (see, for example, references $17,27,39$ ) and has been verified in this work in the case of the mitochondrial RNA species (see below). Given values for $S(t)$ and $R(t)$ for various times, the equation can be solved numerically for the values of $k_{s}$ and $k_{d}$ by making use of an appropriate computer program (23). From $k_{d}$, the half-life of the RNA of interest is calculated:

$$
t_{1 / 2}=\frac{\ln 2}{k_{d}}
$$

In this work, for calculating the rate constants of decay and the rate constants of synthesis, the UTP and CTP specific activities $\left({ }^{3} \mathrm{H} /{ }^{32} \mathrm{P}\right)$ corresponding to each time point, weighted for their proportion in an average $\mathrm{H}$-strand transcript (W. M. Brown, Ph.D. thesis, California Institute of 
Technology, Pasadena, 1976), were added, and the average NTP ${ }^{3} \mathrm{H} /{ }^{32} \mathrm{P}$ ratio thus obtained was converted to the average ${ }^{3} \mathrm{H}$ per mole of NTP by multiplying it by ${ }^{32} \mathrm{P}$ per mole of NTP (estimated to be equal to ${ }^{32} \mathrm{P}$ per mole of orthophosphate in the medium, multiplied by 3 ). The incorporation values for a given RNA species $\left({ }^{3} \mathrm{H} /{ }^{32} \mathrm{P}\right)$ were expressed on a per-cell basis and normalized to the maximum recovery obtained for that species in the various samples of the same experiment, as follows:

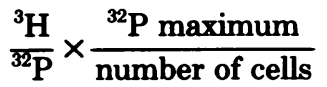

$$
=\text { normalized }{ }^{3} \mathrm{H} \text { per cell }
$$

These normalized data of RNA labeling $[R(t)]$ and the pool specific activity data $[S(t)]$, expressed as indicated above $\left({ }^{3} \mathrm{H}\right.$ per mole of NTP), were utilized in the computer program of Galau et al. (23) to determine the $k_{s}$ and $k_{d}$ values. The half-lives determined in this way for the various mitochondrial RNA species in the experiments illustrated in Fig. 3 are given in Table 1. The calculated half-lives for the rRNA species isolated from total mitochondria (2.5 to $3.5 \mathrm{~h}$ ) appear to be shorter than those calculated for the same species extracted from polysomes $(8$ to $9 \mathrm{~h}$ ). No such difference was observed for the poly(A)-containing RNAs. With the exception of RNA 10, these clearly have a shorter half-life than the rRNA's, varying between about 25 and $90 \mathrm{~min}$ in different putative mRNA's. There is reasonably good agreement among the estimates obtained in different experiments, indicating that neither the differences in cell growth conditions nor the use of the cytoplasmic pool specific activities instead of the mitochondrial pool data had any significant influence on the calculated half-lives. Although the computer program of Galau et al. (23) was developed for nongrowing cells, the use of a program modified for the case of exponentially growing cells gave essentially the same results. RNA 10, which maps in the mitochondrial genome as the 16S rRNA (37) and represents a fraction of this component which binds to oligo(dT)-cellulose (5), has a half-life comparable to that of the rRNA's (Table 1).

Estimation of the nucleotide precursor pool specific activity from the labeling of nascent mitochondrial RNA. In spite of the indications of differences in the labeling kinetics of the nucleotide precursor pools extracted from mitochondria and cytoplasm (Fig. 3F), and in spite of the observation that similar values of specific activity were obtained for the mitochondrial pools derived from the crude mitochondrial fraction and from sucrose gradient-purified organelles, the mitochondrial origin of these putative "mitochondrial" pools has not been demonstrated conclusively. Therefore, it was desirable to repeat the measurements of metabolic stability of mitochondrial RNAs by using the specific activities of precursor pools of unambiguously established mitochondrial derivation. Nascent transcripts of the L-strand of mtDNA seemed to be a suitable material for this analysis. This strand is transcribed at a high rate, and most of these transcripts have a very fast turnover and do not accumulate to any significant extent $(3,13,30)$; furthermore, the availability of a procedure for the isolation from $\mathrm{HeLa}$ cells of substantially pure transcription complexes of mtDNA $(4,13,14)$ provided a convenient source of nascent RNA molecules not contaminated by the few relatively stable L-strand transcripts. In a control experiment utilizing cells labeled with $\left[{ }^{32} \mathrm{P}\right]$ orthophosphate, the RNA extracted from transcription complexes showed, in a $\mathrm{CH}_{3} \mathrm{HgOH}$-agarose slab gel, only a smear of heterogeneous RNA extending over a size range from a few hundred nucleotides to more than 10,000 nucleotides, with traces of $12 \mathrm{~S}$ and $16 \mathrm{~S}$ rRNA's (not shown).

An experiment was carried out in which transcription complexes were isolated from $\mathrm{HeLa}$ cells labeled for $3 \mathrm{~h}$ with $\left[{ }^{32} \mathrm{P}\right]$ orthophosphate and for various times with $\left[{ }^{3} \mathrm{H}\right]$ uridine. The RNA extracted from these transcription complexes was hybridized with an excess of mtDNA L-strands; the alkali-hydrolyzable radioactivity associated with these hybrids was used as an estimate of the specific activity $\left({ }^{3} \mathrm{H} /{ }^{32} \mathrm{P}\right)$ of the mitochondrial nucleotide precursor pools at a given time. A portion of the same cell suspensions was used for the purification of mitochondrial RNA by the micrococcal nuclease procedure. The labeling kinetics of 12S RNA and of two representative poly(A)-containing RNAs (RNAs 11 and 16) in this experiment are shown in Fig. 4A, and the kinetics of labeling of the nascent L-strand transcripts is shown in Fig. 4B. The labeling profiles of the three RNA species closely resemble those obtained in the experiments shown in Fig. 3. Similarly, the half-lives calculated in this experiment for the various RNA species (Table 1) do not appear, in general, to be significantly different from those obtained in the previously described experiments; however, there is a trend towards lower values for the half-lives estimated here: in particular, the half-life calculated for RNA 18 appears to be definitely shorter than that determined for the same RNA in the other experiments.

Cordycepin inhibition experiment. To compare the half-lives of the mitochondrial 
TABLE 1. Half-lives (in minutes) of individual mitochondrial RNA species

\begin{tabular}{|c|c|c|c|c|c|}
\hline \multirow[b]{3}{*}{ RNA species ${ }^{d}$} & \multicolumn{5}{|c|}{ Experimental approach ${ }^{a}$} \\
\hline & \multicolumn{4}{|c|}{ Kinetics of incorporation of label ${ }^{b}$} & \multirow[b]{2}{*}{$\begin{array}{c}\text { Decay of label } \\
\text { after cordycepin } \\
\text { block } \\
\text { (high density, to- } \\
\text { tal mitochon- } \\
\text { dria) }\end{array}$} \\
\hline & $\begin{array}{c}\text { Expt 1 } \\
\text { (exponential; to- } \\
\text { tal mitochondria; } \\
\text { Cyt. UTP and } \\
\text { CTP) }\end{array}$ & $\begin{array}{c}\text { Expt } 2^{c} \\
\text { (exponential; mi- } \\
\text { tochondrial poly- } \\
\text { somes; Cyt. UTP } \\
\text { and CTP) }\end{array}$ & $\begin{array}{c}\text { Expt } 3 \\
\text { (high density; to- } \\
\text { tal mitochondria; } \\
\text { Mit. UTP) }\end{array}$ & $\begin{array}{c}\text { Expt } 4 \\
\text { (high density; to- } \\
\text { tal mitochondria; } \\
\text { nascent L-tran- } \\
\text { scripts) }\end{array}$ & \\
\hline \multicolumn{6}{|l|}{ Oligo(dT) unbound } \\
\hline 16S rRNA & 215 & 499 & 127 & & 282 \\
\hline 12S rRNA & 208 & 537 & 158 & 146 & \\
\hline \multicolumn{6}{|l|}{ Oligo(dT) bound } \\
\hline 2 & & & $<5$ & & 7 \\
\hline 4 & & & & & 39 \\
\hline 5 & & & 28 & 34 & 87 \\
\hline 6 & & & & 20 & 16 \\
\hline 7 & 47 & & 51 & 27 & 112 \\
\hline 9, COI mRNA & 67 & $57(80)$ & 62 & 60 & 116 \\
\hline 10 & 185 & (124) & & & \\
\hline 11 , cytochrome $b$ mRNA & 53 & $30(32)$ & 28 & 25 & 56 \\
\hline 12 & 73 & 38 (38) & 30 & 25 & 51 \\
\hline 13 & & $36(51)$ & 25 & & \\
\hline 14, ATPase 6 mRNA & 59 & $71(103)$ & 88 & & 1,1 \\
\hline 15, COIII mRNA & 71 & $59(87)$ & 62 & 65 & 141 \\
\hline 16, COII mRNA & 77 & 59 (111) & 75 & 44 & 191 \\
\hline 17 & & & 34 & & \\
\hline 18 & 67 & (69) & 57 & 19 & \\
\hline
\end{tabular}

${ }^{a}$ Experimental conditions are given in parentheses as follows: cell conditions; source of material; precursor pool utilized. Cyt., Cytoplasmic; Mit., mitochondrial.

${ }^{b}$ Experiments 1, 2, 3, and 4 summarized here are illustrated in Fig. 3A,D, 3B,E, 3C,F, and Fig. 4, respectively. 2.

${ }^{c}$ Numbers in parentheses pertain to another experiment carried out under the same conditions as experiment

${ }^{d}$ COI, Cytochrome $c$ oxidase subunit 1; ATPase, adenosine triphosphatase.

' In this experiment, the expected cytoplasmic CTP specific activities were estimated from the UTP specific activities, assuming a behavior similar to that of the UTP and CTP pools in experiment 2.

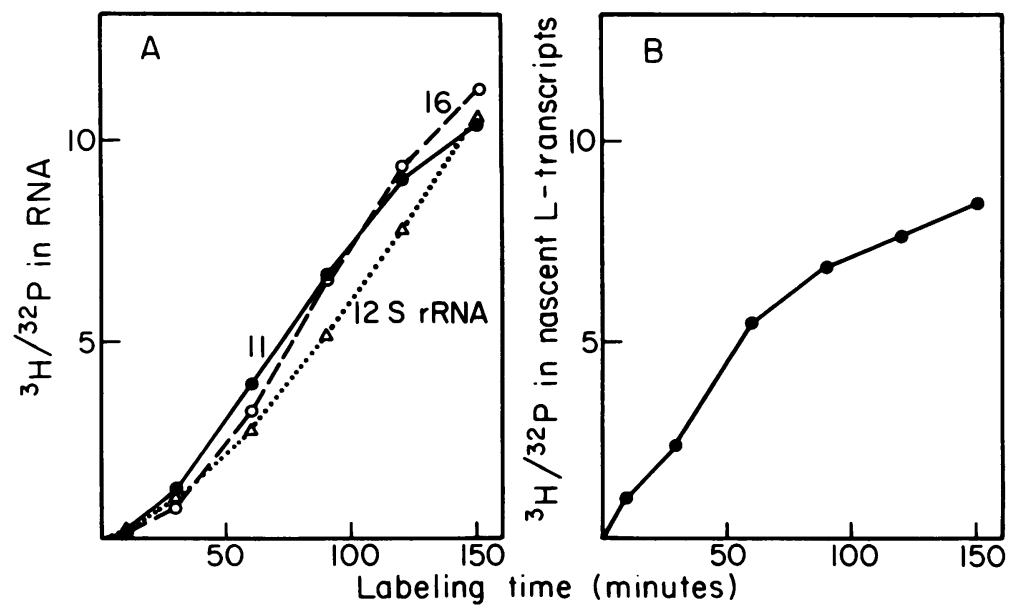

Fig. 4. Kinetics of labeling with $\left[5{ }^{3} \mathrm{H}\right]$ uridine of three representative mitochondrial RNAs (A) and of nascent $L$-strand transcripts (B). Cell suspensions at a high density were labeled for $3.5 h$ with $\left.{ }^{32} P\right]$. orthophosphate and for different times with $\left[5-{ }^{3} \mathrm{H}\right]$ uridine. One-half of the mitochondrial fraction was treated with micrococcal nuclease and used for RNA extraction; the other half was purified by banding in a 1.0 to 1.7 $M$ sucrose two-step gradient and used for isolation of transcription complexes. The labeling of the nascent $L$ strand transcripts was determined as detailed in the text. 
RNA species estimated by analysis of their kinetics of labeling with those measured after block of RNA synthesis, a "chase" experiment utilizing cordycepin was performed. This drug ( 3 '-deoxyadenosine) had been previously reported to inhibit mitochondrial RNA synthesis $(25,45)$ and had been used to measure the decay of mitochondrial 12S and 16S rRNA in HeLa cells labeled before drug treatment (45). To verify the rapidity and extent of cordycepin block of mitochondrial RNA synthesis, the effect of drug treatment on the initial rate of labeling with $\left[5-{ }^{3} \mathrm{H}\right]$ uridine of the individual rRNA and poly(A)-containing RNA species was first investigated. HeLa cells, treated for various lengths of time with the drug at $50 \mu \mathrm{g} / \mathrm{ml}$, were labeled for $10 \mathrm{~min}$ with $\left[5-{ }^{3} \mathrm{H}\right]$ uridine. A constant amount of ${ }^{32} \mathrm{P}$-labeled cells was added to each sample after harvesting to provide an internal marker for the identification by autoradiography of the individual RNA species and for correction of differences in recovery from time point to time point. Figure 5 shows that cordycepin blocked, with varying effectiveness, the appearance of label in all RNA species investigated, with the exception of RNA 18. After $15 \mathrm{~min}$ of drug treatment, the inhibition was 90 to $100 \%$ complete in the different species. However, there appears to be a considerable variation among these in the extent of inhibition of labeling by the drug after shorter times of treatment. The labeling of $12 \mathrm{~S}$ rRNA was inhibited only about $25 \%$ after $2.5 \mathrm{~min}$ and about $45 \%$ after $5 \mathrm{~min}$; the labeling of polyadenylated RNA 18 was not inhibited at all by the drug even after $15 \mathrm{~min}$ of treatment (Fig. 5, insert).

Cordycepin chase experiment. Except for
12S rRNA and RNA 18, the block of labeling of the individual RNA species by cordycepin appeared to be sufficiently rapid and complete to allow meaningful determinations of metabolic stabilities. Therefore, a chase experiment was carried out by prelabeling cell suspensions with $\left[{ }^{32} \mathrm{P}\right.$ ] orthophosphate for $2.5 \mathrm{~h}$, adding cordycepin at $50 \mu \mathrm{g} / \mathrm{ml}$, and incubating the samples for various times before harvesting; a constant amount of $\left[{ }^{3} \mathrm{H}\right]$ uridine-labeled cells was added to each culture after harvesting to correct for differences in recovery. Figure 6 shows the electrophoretic pattern of the poly(A)-containing RNA, as determined by autoradiography, after various times of cordycepin treatment. The two largest labeled RNA species, RNAs 1 and 2, lost radioactivity very rapidly, so that they completely or almost completely disappeared after 15 and $30 \mathrm{~min}$, respectively, of cordycepin treatment. RNAs 3, 4, and 6 decayed more slowly, whereas the other RNA species appeared to be even more stable. The RNA components were eluted from the gel as described in Materials and Methods. The temporal pattern of radioactivity in the individual species, corrected for differences in recovery, is shown in Fig. 7, and the half-lives, derived from the slope of the line fit by the least-squares method to each set of points, are listed in Table 1. These half-lives, in the cases in which a comparison is possible [16S rRNA and poly(A)-containing RNAs 5 to 16], appear, in general, to be significantly longer than those determined from the kinetics of labeling of the individual RNA species, although of the same order of magnitude. With the exception of RNA 5, the larger RNA species (1 to 6) clearly appear to have a shorter half-life than the other

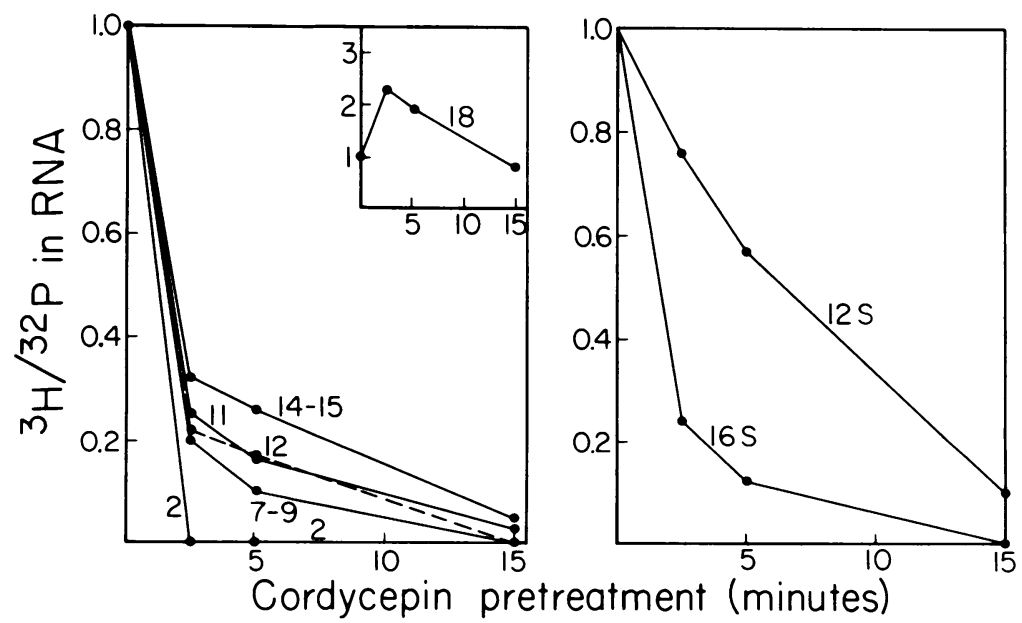

FIG. 5. Effect of cordycepin on the pulse-labeling of individual mitochondrial RNA species. The cells were exposed for $10 \mathrm{~min}$ to $\left[5{ }^{3} \mathrm{H}\right]$ uridine after different times of cordycepin $(50 \mu \mathrm{g} / \mathrm{ml})$ treatment, and the RNA was then extracted from the micrococcal nuclease-treated mitochondrial fraction. See text for details. 


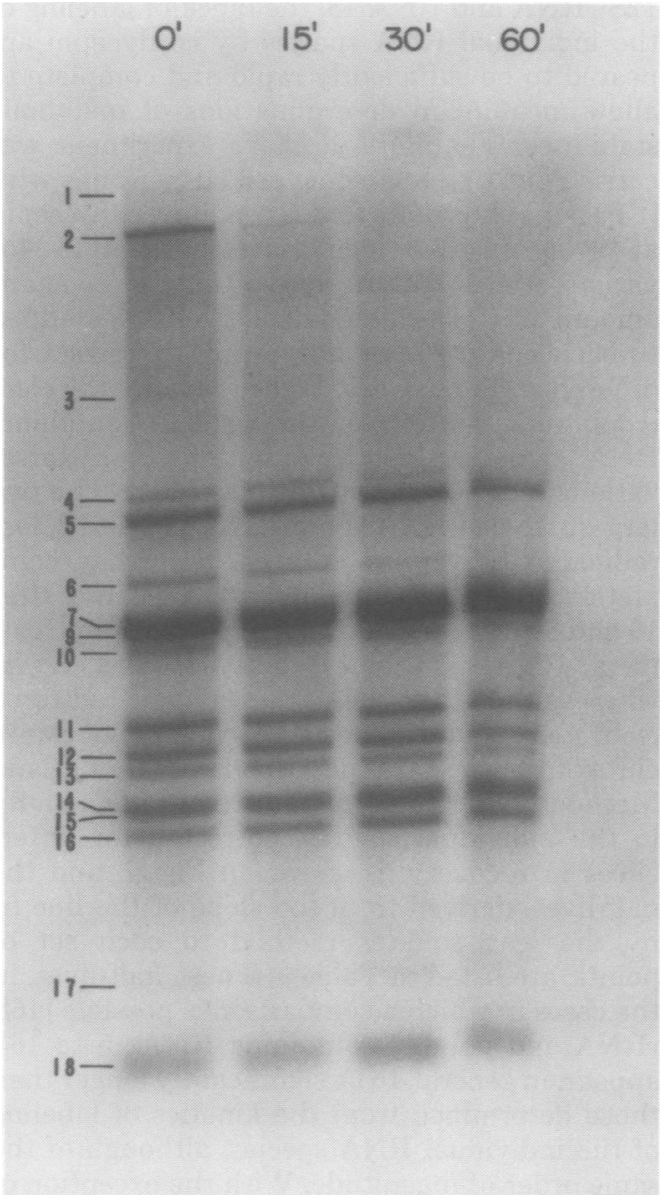

Fig. 6. Autoradiogram, after electrophoresis through an agarose- $\mathrm{CH}_{3} \mathrm{HgOH}$ gel, of the mitochondrial poly $(A)$-containing $R N A$ after different times of cordycepin block of RNA synthesis. The cells, labeled with [ ${ }^{32} P$ ]orthophosphate for $2.5 h$, were exposed for various lengths of time to cordycepin $(50 \mu \mathrm{g} / \mathrm{ml})$ and then mixed with a constant amount of $\left[{ }^{3} H\right]$ uridinelabeled cells, and the RNA was extracted from the micrococcal nuclease-treated mitochondrial fraction. See text for details.

species. Thus, a half-life of about $7 \mathrm{~min}$ was estimated for RNA 2, and it seems likely from the autoradiogram that RNA 1 has a half-life shorter than $10 \mathrm{~min}$ and RNA 3 has a half-life of $<15$ min.

Rates of synthesis and steady-state amounts of mitochondrial RNA species. The numerical solution of equation 1 provided a direct estimate of $k_{s}$, the rate constant of synthesis, for the individual RNA species analyzed. Such rates of synthesis are listed in Table 2 for an experiment in which the cells were labeled for $24 \mathrm{~h}$ with $\left[{ }^{32} \mathrm{P}\right]$ orthophosphate under conditions of exponential growth (these condi-

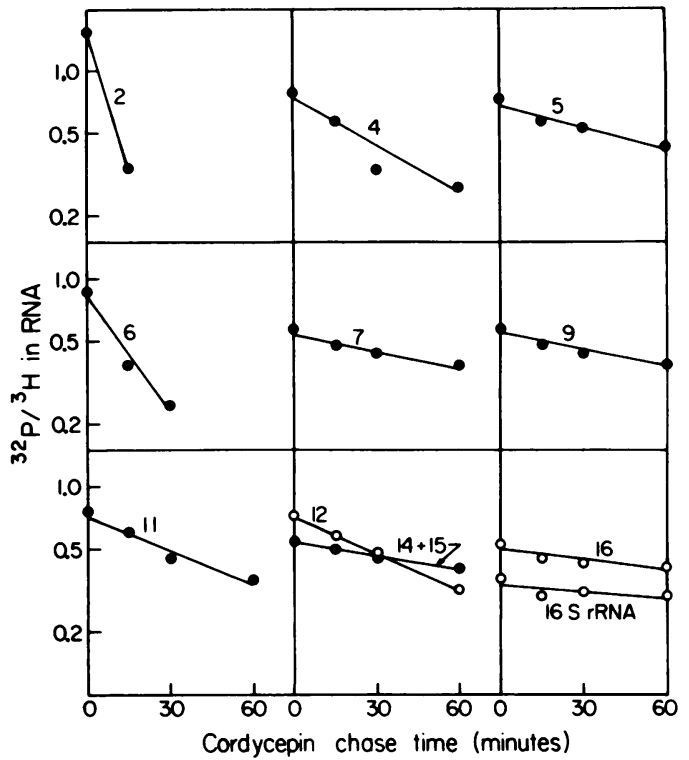

Fig. 7. Decay of the ${ }^{32} P$ radioactivity in the individual mitochondrial RNA species in the cordycepin chase experiment shown in Fig. 6. The ${ }^{32} \mathrm{P} /{ }^{3} \mathrm{H}$ ratios have been plotted on a semilogarithmic scale, and the best fitting lines, as determined by the leastsquares method, have been drawn for each RNA species.

tions ensuring uniform ${ }^{32} \mathrm{P}$ labeling of all RNA species, a prerequisite for a correct $k_{s}$ estimation [see below]) and in which the RNA from the total mitochondrial fraction was analyzed (Fig. $3 A$ and $D$; experiment 1 , Table 1). The rates of synthesis are similar for the different polyadenylated species, varying between 0.7 molecule/ min per cell for RNA 7 and 2.1 molecules/min per cell for RNA 15. By contrast, the rate of synthesis of 12S rRNA is 50 to 100 times higher. The rate of synthesis of 16S rRNA (not shown) is similarly higher ( 24 times); however, the well-known tendency to degradation of this RNA species and its resulting lower than expected yield (7), observed also in this work, make this estimate less reliable. The ratios $k_{s} / k_{d}$ for the individual RNAs in the same experiment, which provide estimates of their steady-state amounts per cell, are also given in Table 2. The molar amount of 12S rRNA appears to be 150 to 650 times higher than that of the various poly(A)-containing RNAs. These values can be compared with the molar amounts per cell estimated from the recovery of ${ }^{32} \mathrm{P}$-labeled RNA species in the same experiment. There is very good agreement between the two sets of values, except in the case of 12S rRNA, for which the direct determination yielded somewhat less than half the calculated amount, and in the case of 
TABLE 2. Rate of synthesis and steady-state amount of individual mitochondrial RNA species ${ }^{a}$

\begin{tabular}{|c|c|c|c|}
\hline \multirow{2}{*}{ RNA species ${ }^{b}$} & \multirow{2}{*}{$\begin{array}{l}\text { Rate of } \\
\text { synthesis } \\
\left(k_{s}\right)(\text { no. } \\
\text { of mole- } \\
\text { cules/min } \\
\text { per cell) }\end{array}$} & \multicolumn{2}{|c|}{$\begin{array}{c}\text { Steady-state amt } \\
\text { (no. of molecules/ } \\
\text { cell) }\end{array}$} \\
\hline & & $k_{s} / k_{d}$ & $\begin{array}{c}\text { Direct } \\
\text { determi- } \\
\text { nation }\end{array}$ \\
\hline \multicolumn{4}{|l|}{ Oligo(dT) unbound } \\
\hline $12 \mathrm{~S}$ rRNA & 99 & 29,600 & 12,600 \\
\hline \multicolumn{4}{|l|}{ Oligo(dT) bound } \\
\hline 7 & 0.7 & 45 & 45 \\
\hline 9, COI mRNA & 1.1 & 105 & 100 \\
\hline 10 & & & 65 \\
\hline $\begin{array}{l}\text { 11, cytochrome } b \\
\text { mRNA }\end{array}$ & 1.6 & 125 & 130 \\
\hline 12 & 1.5 & 160 & 175 \\
\hline 13 & & & 165 \\
\hline 14, ATPase 6 mRNA & 1.7 & 145 & 190 \\
\hline 15, COIII mRNA & 2.1 & 215 & 220 \\
\hline 16, COII mRNA & 1.9 & 210 & 225 \\
\hline 18 & 1.7 & 165 & 440 \\
\hline
\end{tabular}

${ }^{a} k_{s}$ and $k_{d}$ values reported here were obtained in the experiment illustrated in Fig. 3A; the absolute yield of the individual RNA species in the same experiment was determined from the amount of ${ }^{32} \mathrm{P}$ radioactivity recovered and the specific activity of the orthophosphate in the medium.

${ }^{b}$ COI, Cytochrome $c$ oxidase subunit I; ATPase, adenosine triphosphatase.

c Represents the rate of appearance of mature RNA species.

RNA 18 , which gave an approximately 2.5 times higher direct estimate. It should be noted that the values given above for the rates of synthesis and steady-state amounts of mitochondrial RNA species represent minimum estimates, in view of the losses associated with the isolation procedure.

\section{DISCUSSION}

Methodological aspects. In this work, ${ }^{32} \mathrm{P}$ radioactivity was utilized to estimate the mass of the individual RNA species. In the experiments in which absolute synthesis rates were determined, uniform ${ }^{32} \mathrm{P}$ labeling of all RNA species was necessary to allow the calculation of the mass of the recovered RNA from the phosphate specific activity in the medium. For this purpose, exponentially growing cells were labeled with $\left[{ }^{32} \mathrm{P}\right]$ orthophosphate for $24 \mathrm{~h}$, a time sufficiently long to ensure essentially uniform labeling of all of the RNA species, in view of the relatively short half-lives of mitochondrial RNAs. In the experiments in which only the half-lives of the RNAs were of interest, uniform ${ }^{32} \mathrm{P}$ labeling of all of the species was not essential, the only requirement being that a given RNA species be labeled to the same specific activity for all time points in the same experiment. In fact, any deviation from uniform labeling of the mitochondrial RNAs occurring in the short-labeling experiments, although it would introduce an error in the estimation of ${ }^{3} \mathrm{H}$ per mole of NTP and therefore in the absolute $k_{s}$ determination, would have no effect on the $k_{d}$ determination.

The use of the kinetics of labeling of nascent L-strand transcripts to estimate the changes in specific activity of the mitochondrial UTP and CTP pools should, in principle, be the most reliable approach, since it avoids the difficulties involved in the isolation of pure mitochondrial NTP pools and is not affected by a possible intramitochondrial compartmentation of these pools. The values obtained for the half-lives of individual RNA species, using this approach to estimate the nucleotide precursor specific activities, were similar to those estimated by using the direct measurements of UTP and CTP pool specific activity, pointing to the general validity of the pool estimates used for the present determinations.

Metabolic instability of mitochondrial RNA species. The most significant result of this work is the observation that both the mature mitochondrial rRNA's and the putative $\mathrm{H}$ strand-coded mRNA species [poly(A)-containing RNAs $5,7,9$, and 11 to 16] are metabolically unstable. Their half-lives, as determined in the kinetics of labeling experiments, were found to be 2.5 to $3.5 \mathrm{~h}$ for the rRNA components and to range between 25 and $90 \mathrm{~min}$ for the different mRNA's. The putative mRNA's $5,7,11$ (cytochrome $b$ mRNA [Attardi et al., in press; Barrell et al., in press]), 12, and 13 exhibited consistently lower half-lives than mRNA's 9 (cytochrome $c$ oxidase subunit I mRNA [16, Barrell et al., in press]), 14 (adenosine triphosphatase 6 mRNA [Attardi et al., in press; Barrell et al., in press]), 15 (cytochrome $c$ oxidase subunit III mRNA [Attardi et al., in press; Barrell et al., in press]), and 16 (cytochrome $c$ oxidase subunit II mRNA $[11,16,38])$. The half-lives of the mRNA's extracted from partially purified polysomes were similar to those obtained for the mRNA's extracted from total mitochondria. By contrast, the half-lives of the rRNA species from polysomes were considerably higher than the values obtained for the total mitochondrial rRNA's. This suggests the possibility that a fraction of rRNA incorporated into ribosomal particles and participating in protein synthesis is metabolically more stable than the remainder. Poly(A)containing RNA 18, an mtDNA L-strand-coded RNA species, which had been previously de- 
scribed as 7S RNA on the basis of its sedimentation constant (35), revealed a half-life comparable to that of the putative $\mathrm{H}$-strand-coded mRNA's, i.e., about $1 \mathrm{~h}$; the reason for the shorter half-life $(\sim 20 \mathrm{~min})$ determined for this species in the experiment utilizing the L-strand nascent transcripts for the estimation of the precursor pool labeling is not clear.

Effect of cordycepin on mitochondrial RNA metabolism. The adenosine analog cordycepin has been extensively used to study RNA synthesis and processing in eucaryotic cells. In particular, mitochondrial RNA synthesis has been reported to be inhibited by cordycepin, both the rRNA and poly(A)-containing RNA species being affected $(25,45)$. This inhibition was interpreted to occur at the level of transcription. In our work, by measuring the initial rate of $\left[5-{ }^{3} \mathrm{H}\right]$ uridine incorporation into individual mitochondrial RNA species after short lengths of cordycepin treatment, it has been possible to investigate the early effects of the drug and to detect significant differences among the various RNA species in their response to cordycepin. Thus, the labeling of RNA 2 was very rapidly blocked, whereas that of $12 \mathrm{~S}$ rRNA was only slowly affected, with the 16S rRNA and the Hstrand-coded putative mRNA's showing an intermediate sensitivity to the drug.

Recent mapping and RNA and DNA sequencing studies have given strong support to a model of H-strand transcription in the form of a single molecule starting near the origin of replication and extending uninterruptedly up to the distal end of the D-loop $(9,13,37,38 \mathrm{a})$. These polycistronic transcripts would be processed, probably while still being synthesized, by precise endonucleolytic cleavages occurring in most cases before and after a tRNA sequence, to yield the mature products or, in some cases, processing intermediates. It has been further suggested that polyadenylation may be linked in some way to the processing step releasing the $3^{\prime}$-end of these RNA products (37, 38a; Attardi et al., in press). In this work, no gradient of responses to cordycepin treatment which could be related to the map position of the transcripts (Fig. 1C), as would be expected if the drug were to interfere with chain elongation of the postulated polycistronic transcripts, was observed in the labeling of the various mitochondrial rRNA and $\mathrm{H}$ strand-coded mRNA species (Fig. 5), apart from the lower sensitivity of the 12S rRNA. Therefore, the present observations tend to support a mechanism of action of cordycepin on the processing of the single $\mathrm{H}$-strand transcripts, rather than an effect of the drug on mtDNA transcription. A possible interference of cordycepin with the processing of the $\mathrm{H}$-strand transcripts at the level of polyadenylation would be in keeping with its effects on the processing of heterogeneous nuclear RNA $(19,40)$. Cordycepin has been previously reported to have only a limited effect on mitochondrial polyadenylation (25); however, it was not established whether the polyadenylation observed in those experiments represented a true de novo formation of $\operatorname{poly}(\mathrm{A})$ chains on presynthesized transcripts, rather than an aberrant poly(A) addition to RNA fragments, as observed after ethidium bromide inhibition (25), or some kind of poly(A) turnover similar to that shown to occur normally in both the nucleus and the cytoplasm (20).

Cordycepin was found not to inhibit the labeling of the L-strand-coded polyadenylated RNA species 18, in sharp contrast to the strong inhibition of the labeling of the large L-strandcoded RNA 2. The significance of this observation is not clear.

Cordycepin chase experiment. The halflives of the mitochondrial mRNA's determined in the cordycepin chase experiment were all longer, by a factor of 1.5 to 2.5 , than those estimated in the labeling kinetics experiments, ranging between $50 \mathrm{~min}$ and more than $3 \mathrm{~h}$ for the various putative mRNA's. This difference cannot be entirely accounted for by an incomplete block of labeling and suggests the possibility of a coupling of RNA degradation to RNA synthesis or processing (see below). A half-life of about 280 min was determined for $16 \mathrm{~S}$ rRNA in this experiment. Previously, a half-life of $3 \mathrm{~h}$ had been reported for the two rRNA components after blocking RNA synthesis by either cordycepin (45) or ethidium bromide (46).

The cordycepin chase experiment allowed an estimation of the half-life of large RNA species which, due to their marginal amounts, could not be analyzed quantitatively in the labeling kinetics experiments. Thus, the three large L-strandcoded RNAs, 1, 2, and 3, were found to be very unstable after cordycepin block, with an estimated half-life shorter than $15 \mathrm{~min}$. These RNA species may be precursors or intermediates in the processing of L-strand-coded tRNA's; however, it seems possible that these transcripts or their derivatives may function as mRNA's or may serve some other role, possibly related to the $\mathrm{H}$-strand gene expression (37). RNAs 4 and 6 clearly had a shorter half-life than the rRNA's and putative mRNA's.

Physiological significance and control of mitochondrial RNA turnover. Mitochondrial rRNA's in HeLa cells have a short half-life relative to the cell generation time, and, in this respect, their behavior is different from that of the rRNA species from all rapidly growing cell systems so far investigated, both bacterial (24) 
and of animal source $(21,43)$. Similarly, the fairly high rate of turnover of the HeLa cell mitochondrial mRNA species contrasts with the well-documented long half-life of the majority of cytoplasmic mRNA's in mammalian cells cultured in vitro $(31,41,43)$.

Consistent with the idea that at least one control of mitochondrial gene expression operates at the level of RNA utilization and stability are the results of recent experiments which strongly suggest that the stability of mitochondrial RNA in in vitro cultured mammalian cells may be subject to feedback control under conditions in which the synthesis of rRNA and mRNA is blocked. Thus, in enucleated African green monkey cells, mitochondrial protein synthesis did not decline significantly for at least 24 $h$ after enucleation, even though mitochondrial RNA synthesis was strongly inhibited under those conditions (22). Similarly, in mouse $L$ $\left(\mathrm{TK}^{-}\right)$cells, the rate of mitochondrial protein synthesis was found not to be appreciably affected for least $48 \mathrm{~h}$ under conditions of extensive inhibition (more than $80 \%$ ) of mitochondrial RNA synthesis resulting from photodamage of bromodeoxyuridine-substituted mtDNA (28). In both of the above-mentioned cases, the size distribution of the mitochondrially synthesized proteins was unchanged. It seems very unlikely that these results can be accounted for by the existence of a large intramitochondrial pool of mRNA. It can likewise be excluded, on the basis of the available evidence, that the existence in mitochondria of stable mRNA's imported from the nucleus would explain the stability of mitochondrial protein synthesis after block of mtDNA transcription in the above-described experiments.

The most plausible explanation of the apparent paradox being considered here is that the stability of mitochondrial RNA had dramatically increased in the experiments discussed above. This intriguing conclusion implies that the metabolic turnover of the rRNA and mRNA species in mammalian mitochondria is linked to some mitochondrial process such as mtDNA transcription or RNA processing and, furthermore, that the levels of mitochondrial RNAs are regulated, at least in part, at the level of decay.

Rates of synthesis of the mature rRNA's and mRNA's. The rate constants of synthesis $\left(k_{s}\right)$ estimated here for the mature rRNA's and mRNA's in exponentially growing cells fall clearly into two classes. One class contains the values obtained for the mRNA's, which are fairly similar to one another, ranging between 1.5 and $2.1 \mathrm{molecules} / \mathrm{min}$ per cell for most of the species. The somewhat lower rates of synthesis calculated for RNA 7 (0.7) and RNA 9 (1.1) may reflect a greater tendency to degradation of the larger molecules during extraction. The rates of synthesis of the rRNA species, using as a representative figure the more reliable value obtained for 12S rRNA, are 50 to 100 times higher than those of the mRNA's. This pattern of synthesis of the RNA species coded for by the H-strand would be consistent with the previously mentioned model of $\mathrm{H}$-strand transcription in the form of a single polycistronic molecule, if these polycistronic transcripts have a high probability of terminating prematurely at some site past the initial stretch of 2,650 nucleotides, which includes the two rRNA sequences and the two adjacent (on the $5^{\prime}$ side) tRNA's (37; Fig. 1C). The alternative possibility that there are two promoters, one for the transcription of the rRNA genes and adjacent tRNA genes and the other for the transcription of the $\mathrm{H}$-strand proteincoding sequences and tRNA genes lying downstream relative to the rRNA genes, seems less likely in view of the butt-jointing of the tRNA ${ }^{\text {Leu }}$ gene to the $3^{\prime}$ end of the 16S rRNA gene (38a) and of the immediate contiguity of the sequence coding for RNA 13 with the tRNA ${ }^{\text {Leu }}$ gene (29a). However, this possibility cannot be rigorously excluded on the basis of the available evidence.

The calculated rates of appearance of mitochondrial mRNA's, even though minimum estimates, are extremely low. Considering that each HeLa cell contains several thousand mtDNA molecules (12), these rates are equivalent to one new molecule, or less, of each mRNA species per mitochondrial genome per cell generation. The rate of appearance of the rRNA's would be 50 to 100 molecules of each species per mitochondrial genome per cell generation $(24 \mathrm{~h})$. One can try to estimate a minimum overall rate of transcription of the $\mathrm{H}$-strand by assuming that the rate of transcription of the first 2,650 nucleotides of the putative single transcription unit is the same as the rate of appearance experimentally found for 12S rRNA, whereas the rate of transcription of the remainder of the transcription unit up to the distal end of the D-loop is approximately equal to the average found for the rates of synthesis of the mRNA species analyzed here. The value thus obtained is $\sim 2.6 \times 10^{5}$ nucleotides/ min per cell. Considering that the rate of transcription of the L-strand is at least two to three times higher than that of the H-strand (13), one can estimate a total rate of transcription of mtDNA of at least $0.8 \times 10^{6}$ to $1.0 \times 10^{6}$ nucleotides/min per cell. This rate has to be compared with that previously estimated on the basis of the initial rate of $\left[5{ }^{3} \mathrm{H}\right]$ uridine incorporation into the mitochondrial fraction $\left(\sim 4 \times 10^{6} \mathrm{nu}-\right.$ cleotides/min per cell; 8 ). Taking into account the unavoidable losses of RNA connected with 
the lengthy purification procedure used in this work, the two figures are reasonably close and suggest that a substantial part, if not all, of the $\mathrm{H}$-strand transcripts in HeLa cells are processed into mature RNA molecules. The striking conclusion of this analysis is, therefore, that the major portion of the $\mathrm{H}$-strand in each mtDNA molecule is transcribed infrequently, possibly as rarely as once or twice per cell generation.

Size of the rRNA and mRNA pools in HeLa cell mitochondria. The values for the steady-state amount of the individual rRNA and mRNA species derived in this work from the $k_{s}$ / $k_{d}$ ratios are in excellent to reasonable agreement with those directly determined from the recovery of the ${ }^{32} \mathrm{P}$-labeled species. The direct estimates are probably more reliable because they were not subject to the errors inherent in the measurements of precursor pool specific activity and in the computer data fitting. As expected from the rates of synthesis and the halflives, there is in HeLa cell mitochondria a large excess of rRNA over the mRNA's, ranging between 60 - and 300-fold for the different mRNA's. Assuming an average content of 500 mitochondria per cell (42), one can estimate that, as a minimum, there are 0.1 to 1 molecule of each putative mRNA and about 25 molecules of each rRNA species per organelle.

\section{ACKNOWLEDGMENTS}

These investigations were supported by Public Health Service grant GM-11726 from the National Institutes of Health.

We are very grateful to Eric Davidson for making the computer program used here available to us and for valuable advice and discussions. The technical assistance of Arger Drew and Benneta Keeley is gratefully acknowledged.

\section{LTERATURE CITED}

1. Aloni, Y., and G. Attardi. 1971. Expression of the mitochondrial genome in HeLa cells. IV. Titration of mitochondrial genes for 16S, 12S and 4S RNA. J. Mol. Biol. 55:271-276.

2. Aloni, Y., and G. Attardi. 1971. Expression of the mitochondrial genome in HeLa cells. II. Evidence for complete transcription of mitochondrial DNA. J. Mol. Biol. 55:251-270.

3. Aloni, Y., and G. Attardi. 1971. Symmetrical in vivo transcription of mitochondrial DNA in HeLa cells. Proc. Natl. Acad. Sci. U.S.A. 68:1757-1761.

4. Aloni, Y., and G. Attardi. 1972. Expression of the mitochondrial genome in HeLa cells. XI. Isolation and characterization of transcription complexes of mitochondrial DNA. J. Mol. Biol. 70:363-373.

5. Amalric, F., C. Merkel, R. Gelfand, and G. Attardi. 1978. Fractionation of mitochondrial RNA from HeLa cells by high-resolution electrophoresis under strongly denaturing conditions. J. Mol. Biol. 118:1-25.

6. Angerer, L., N. Davidson, W. Murphy, D. Lynch, and G. Attardi. 1976. An electron microscope study of the relative positions of the $4 S$ and ribosomal RNA genes in HeLa cell mitochondrial DNA. Cell 9:81-90.

7. Attardi, B., and G. Attardi. 1971. Expression of the mitochondrial genome in HeLa cells. I. Properties of the discrete RNA components from the mitochondrial fraction. J. Mol. Biol. 55:231-249.

8. Attardi, G., and B. Attardi. 1969. The informational role of mitochondrial DNA, p. 245-283. In E. W. Hanly (ed.), Problems in biology: RNA in development. University of Utah Press, Salt Lake City.

9. Attardi, G., P. Cantatore, E. Ching, S. Crews, R. Gelfand, C. Merkel, J. Montoya, and D. Ojala. 1980. The remarkable features of gene organization and expression of human mitochondrial DNA, p. 103-119. In A. M. Kroon and C. Saccone (ed.), The organization and expression of the mitochondrial genome. NorthHolland Publishing Co., Amsterdam.

10. Barrell, B. G., S. Anderson, A. T. Bankier, M. H. L. de Bruijn, E. Chen, A. R. Coulson, J. Drouin, I. C. Eperon, D. P. Nierlich, B. A. Roe, F. Sanger, P. H. Schreier, A. J. H. Smith, R. Staden, and I. G. Young. 1980. Different pattern of codon recognition by mammalian mitochondrial tRNAs. Proc. Natl. Acad. Sci. U.S.A. 77:3164-3166.

11. Barrell, B. G., A. T. Bankier, and J. Drouin. 1979. A different genetic code in human mitochondria. Nature (London) 282:189-194.

12. Bogenhagen, D., and D. A. Clayton. 1974. The number of mitochondrial deoxyribonucleic acid genomes in mouse $L$ and human HeLa cells. J. Biol. Chem. 249: 7991-7995.

13. Cantatore, P., and G. Attardi. 1980. Mapping of nascent light and heavy strand transcripts on the physical map of HeLa cell mitochondrial DNA. Nucleic Acids Res. 8: 2605-2624.

14. Carré, D., and G. Attardi. 1978. Biochemical and electron microscopic characterization of DNA-RNA complezes from HeLa cell mitochondria. Biochemistry 17: 3263-3273.

15. Cashel, M., R. A. Lazzarini, and B. Kalbacher. 1969. An improved method for thin-layer chromatography of nucleotide mixtures containing ${ }^{32} \mathrm{P}$-labeled orthophosphate. J. Chromatogr. 40:103-109.

16. Chomyn, A., M. W. Hunkapiller, and G. Attardi. 1981. Alignment of the amino terminal amino acid sequence of human cytochrome $c$ oxidase subunits I and II with the sequence of their putative mRNAs. Nucleic Acids Res. 9:867-877.

17. Cowan, N. J., and C. Milstein. 1974. Stability of cytoplasmic ribonucleic acid in a mouse myeloma: estimation of the half-life of the messenger RNA coding for an immunoglobulin light chain. J. Mol. Biol. 82:469-481.

18. Crews, S., and G. Attardi. 1980. The sequences of the small ribosomal RNA gene and the phenylalanine tRNA gene are joined end to end in human mitochondrial DNA. Cell 19:775-784.

19. Darnell, J. E., L. Philipson, R. Wall, and M. Adesnik. 1971. Polyadenylic acid sequences: role in conversion of nuclear RNA into messenger RNA. Science 174:507510.

20. Diez, J., and G. Brawerman. 1974. Elongation of the polyadenylate segment of messenger RNA in the cytoplasm of mammalian cells. Proc. Natl. Acad. Sci. U.S.A. 71:4091-4095.

21. Emerson, C. P., Jr. 1971. Regulation of the synthesis and the stability of ribosomal RNA during contact inhibition of growth. Nature (London) New Biol. 232:101106.

22. England, J., P. Costantino, and G. Attardi. 1978. Mitochondrial RNA and protein synthesis in enucleated African green monkey cells. J. Mol. Biol. 119:445-462.

23. Galau, G. A., E. D. Lipeon, R. J. Britten, and E. H. Davidson. 1977. Synthesis and turnover of polysomal mRNAs in sea urchin embryos. Cell 10:415-432.

24. Gausing, K. 1977. Regulation of ribosome production in Escherichia coli: synthesis and stability of ribosomal RNA and of ribosomal protein messenger RNA at different growth rates. J. Mol. Biol. 115:335-354. 
25. Hirsch, M., and S. Penman. 1974. Post-transcriptional addition of polyadenylic acid to mitochondrial RNA by a cordycepin-insensitive process. J. Mol. Biol. 83:131142.

26. Humphreys, T. 1973. Quantitative measurement of RNA synthesis. In M. Chrispeels (ed.), Molecular techniques and approaches in developmental biology. John Wiley \& Sons, Inc., New York.

27. Hunt, J. A. 1974. Half-life and rate of synthesis of globin messenger ribonucleic acid. Biochem. J. 138:487-498.

28. Lansman, R. A., and D. A. Clayton. 1975. Mitochondrial protein synthesis in mouse L-cells: effect of selective nicking of mitochondrial DNA. J. Mol. Biol. 99: 777-793.

29. Lynch, D. C., and G. Attardi. 1976. Amino acid specificity of the transfer RNA species coded for by HeLa cell mitochondrial DNA. J. Mol. Biol. 102:125-141.

29a.Montoya, J., D. Ojala, and G. Attardi. 1981. Distinctive features of the 5 '-terminal sequences of the human mitochondrial mRNAs. Nature (London) 290:465-470.

30. Murphy, W. I., B. Attardi, C. Tu, and G. Attardi. 1975. Evidence for complete symmetrical transcription in vivo of mitochondrial DNA in HeLa cells. J. Mol. Biol. 99:809-814.

31. Murphy, W. I., and G. Attardi. 1973. Stability of cytoplasmic messenger RNA in HeLa cells. Proc. Natl. Acad. Sci. U.S.A. 70:115-119.

32. Neuhard, J., E. Randerath, and K. Randerath. 1965. Ion exchange thin layer chromatography. XIII. Resolution of complex nucleoside triphosphate mixtures. Anal. Biochem. 13:211-222.

33. Nobrega, F. G., and A. Tzagoloff. 1980. Assembly of the mitochondrial membrane system. DNA sequence and organization of the cytochrome b gene in Saccharomyces cerevisiae D273-10B. J. Biol. Chem. 255:98289837.

34. Ojala, D., and G. Attardi. 1972. Expression of the mitochondrial genome in HeLa cells. X. Properties of mitochondrial polysomes. J. Mol. Biol. 65:273-289.

35. Ojala, D., and G. Attardi. 1974. Identification and partial characterization of multiple discrete polyadenylic acid- containing RNA components coded for by HeLa cell mitochondrial DNA. J. Mol. Biol. 88:205-219.

36. Ojala, D., and G. Attardi. 1980. Fine mapping of the ribosomal RNA genes of HeLa cell mitochondrial DNA. J. Mol. Biol. 138:411-420.

37. Ojala, D., C. Merkel, R. Gelfand, and G. Attardi. 1980. The tRNA genes punctuate the reading of genetic information in human mitochondrial DNA. Cell 22:393403.

38. Ojala, D., J. Montoya, and G. Attardi. 1980. The putative mRNA for subunit II of cytochrome $c$ oxidase in human mitochondria starts directly at the translation initiator codon. Nature (London) 287:79-82.

38a.Ojala, D., J. Montoya, and G. Attardi. 1981. The tRNA punctuation model of RNA processing in human mitochondria. Nature (London) 290:470-474.

39. Palmiter, R. D. 1973. Rate of ovalbumin messenger ribonucleic acid synthesis in the oviduct of estrogenprimed chicks. J. Biol. Chem. 248:8260-8270.

40. Penman, S., M. Rosbash, and M. Penman. 1970. Messenger and heterogeneous nuclear RNA in HeLa cells: differential inhibition by cordycepin. Proc. Natl. Acad. Sci. U.S.A. 67:1878-1885.

41. Perry, R. P., and D. E. Kelley. 1973. Messenger RNA turnover in mouse L cells. J. Mol. Biol. 79:681-696.

42. Posakony, J. W., J. M. England, and G. Attardi. 1977. Mitochondrial growth and division during the cell cycle in HeLa cells. J. Cell Biol. 74:468-491.

43. Singer, R. H., and S. Penman. 1973. Messenger RNA in HeLa cells: kinetics of formation and decay. J. Mol. Biol. 78:321-334.

44. Thalenfeld, B. E., and A. Tzagoloff. 1980. Assembly of the mitochondrial membrane system. Sequence of the oxi 2 gene of yeast mitochondrial DNA. J. Biol. Chem. 255:6173-6180.

45. Zylber, E., S. Perlman, and S. Penman. 1971. Mitochondrial RNA turnover in the presence of cordycepin. Biochim. Biophys. Acta 240:588-593.

46. Zylber, E., C. Vesco, and S. Penman. 1969. Selective inhibition of the synthesis of mitochondria-associated RNA by ethidium bromide. J. Mol. Biol. 44:195-204. 